(C) О.В. Соколов, 2020

УДК 616.1473-007.64-089

\title{
Диференційований підхід до корекції постхірургічного рецидиву декомпенсованих форм варикозної хвороби вен нижніх кінцівок
}

\author{
О.В. Соколов
}

Дніпропетровська медична академія МОЗ України, кафедра хірургії №2, Дніпропетровськ

\section{Реферат}

Вступ. Незважаючи на те, що безпосередні результати хірургічного лікування варикозної хвороби вен нижніх кінцівок (ВХНК) є загалом успішними, рецидиви захворювання виникають від 20\% до 80\% пацієнтів, в залежності від періоду післяопераційного спостереження. Середня різниця у часі між первинною операцією та хірургічною корекцією рецидиву може складати від 6 до 20 років.

Мета дослідження. Оцінити результати лікування рецидивів варикозної хвороби вен нижніх кінцівок 3 трофічними виразками при використанні ендовенозних методик та класичної хірургії.

Матеріали та методи. У дослідження було включено 23 хворих з рецидивами варикозної хвороби вен нижніх кінцівок у стадії С6 після втручань з кросектомією. Пацієнтів було розділено на дві групи. В I групу було включено 12 пацієнтів, яким було проведено корекцію рецидиву шляхом повторної спроби кросектомії та хірургічного видалення вен шляхом стрипінгу та мініфлебектомії. У ІІ групу ввійшли 11 пацієнтів, яким було проведено корекцію рецидиву шляхом комбінованих ендовенозних втручань 3 використанням радіочастотної абляції залишеної культі та невидаленої частини саженних стовбурів, склеротерапії зон неоваскуляризації та хірургічним видаленням варикозно-деформованих притоків.

Результати досліджень та їх обговорення. Через 2 місяці після проведення втручань венозні трофічні виразки загоїлися у 10 хворих (83,3\%) І групи та 11 хворих $(100,0 \%)$ II групи. Швидкість епітелізації виразок протягом всього періоду спостереження була співставною у обох групах і склала 42,1 \pm 6,4 доби (I група) та 39,2 \pm 6,1 діб (II група). При цьому протягом першого місяця зменшення площі виразки, у відношенні ії у порівнянні зі станом перед операцією у хворих I групи у 2,3 $\pm 0,5$ ( $>0,005)$, у хворих II групи у $2,1 \pm 0,4$ ( $>0,005)$. Повторне відкриття виразки, протягом дворічного періоду спостереження, відбулося у 3 хворих $(25,0 \%)$ I групи. При УЗ-дослідженні у всіх них було виявлено значний горизонтальний рефлюкс по неспроможніхперфорантних венах у підвиразковій ділянці. Рецидивів виразки у II групі не спостерігалося.

Висновки. Ретельне обстеження хворих перед операцією, використання інтраопераційного УЗ-контролю та моніторинг у післяопераційному періоді дозволяють зменшити кількість тактичних помилок у лікувальному процесі рецидивів варикозної хвороби.

Використання ендовенозних методів в лікуванні рецидивів варикозної хвороби вен нижніх кінцівок дозволяє покращити результати лікування та зменшити кількість ускладнень.

Ключові слова: варикозна хвороба, радіочастотна абляція, венозна гемодинаміка, трофічні виразки, рецидив.

Abstract

Differentiated approach to the correction of post-surgical recurrence of decompensated forms of varicose veins of the lower extremities

O.V Sokolov

Dnipropetrovsk Medical Academy of the Ministry of Health of Ukraine, Department of Surgery №2, Dnipropetrovsk

Introduction. Although the immediate results of surgical treatment of varicose veins of the lower extremities (VHNC) are generally successful, recurrences occur in $20 \%$ to $80 \%$ of patients, depending on the period of postoperative follow-up. The average time difference between primary surgery and surgical correction of recurrence can be from 6 to 20 years.

The aim of the study. Evaluate the results of treatment of recurrences of varicose veins of the lower extremities with trophic ulcers using endovenous techniques and classical surgery.

Materials and methods. The study included 23 patients with recurrences of varicose veins of the lower extremities in stage C6 after interventions with crossectomy. Patients were divided into two groups. Group I included 12 patients who underwent recurrence correction by re-attempting crossectomy and surgical removal of veins by stripping and miniphlebectomy. The second group included 11 patients who underwent correction of recurrence by combined endovenous interventions using radiofrequency ablation of the left stump and unremoved part of the trunks, sclerotherapy of neovascularization areas and surgical removal of varicose veins.

Results of the studies and their discussion. Two months after the interventions, venous trophic ulcers healed in 10 patients $(83.3 \%)$ of group I and 11 patients $(100.0 \%)$ of group II. The rate of epithelialization of ulcers throughout the observation period was comparable in both groups and was $42.1 \pm 6.4$ days (group I) and $39.2 \pm 6.1$ days (group II). At the same time during the first month of reduction of the area of an ulcer, in relation to it in comparison with a condition before operation at patients of the I group in $2,3 \pm 0,5$ (p>0,005), at patients of the II group at $2,1 \pm 0,4>0,005$ ).

The reopening of the ulcer during the two-year follow-up period occurred in 3 patients (25.0\%) of group I. Ultrasound examination of all of them revealed significant horizontal reflux in incapable perforating veins in the ulcer area. No recurrence of ulcer in group II was observed.

Conclusions. Careful examination of patients before surgery, the use of intraoperative ultrasound control and monitoring in the postoperative period can reduce the number of tactical errors in the treatment of recurrence of varicose veins.

The use of endovenous methods in the treatment of recurrences of varicose veins of the lower extremities can improve treatment outcomes and reduce the number of complications.

Key words: varicose veins, radiofrequency ablation, venous hemodynamics, venous ulcers, reccurence. 
Вступ. Незважаючи на те, що безпосередні результати хірургічного лікування варикозної хвороби вен нижніх кінцівок (ВХНК) є загалом успішними, рецидиви можуть складати від $20 \%$ у п'ятирічний термін та зростати до $80 \%$ із більшенням періоду післяопераційного спостереження [1]. Надійних даних щодо епідеміології та соціально-екомічного впливу рецидивів варикозної хвороби наразі немає [2]. Середня різниця у часі між первинною операцією та хірургічною корекцією рецидиву може складати від 6 до 20 років [3]. M.Perrin визначив постхірургічний рецидив (REVAS), як повторний прояв вариксів вен у хворих, які раніше мали хірургічне лікування варикозної хвороби нижніх кінцівок $з$ або без використанням додаткової терапії [4]. Прийнято виділяти анатомічний рецидив, визначений за допомогою дуплексного УЗД, який часто є безсимптомним, та клінічний, симптоматичний рецидив [4,5]. Його прояви, особливо у хворих, які страждають на венозну трофічну виразку, значною мірою погіршують якість життя [6].

Відновлення проявів хвороби після класичної хірургії пов'язане, насамперед, 3 явищами неоваскуляризації, включенням у патологічний процес раніше спроможніх додаткових венозних магістралей, внаслідок прогресування хвороби, а також тактичних та технічних недосконалостей у діагностичнолікувальному процесі, які є причиною до $80 \%$ рецидивів [7]. Окремою причиною рецидивів є прояви синдрому тазового венозного повнокрів'я [8]. Хірургічне лікування рецидивів є більш технічно складним, ніж первинні операції та задоволеність пацієнтів після повторних втручань $є$ нижчою [9].

Питання, у яких випадках віддати перевагу тій чи іншій тактиці, залишається відкритим та потребує додаткового дослідження.

Мета дослідження. Порівняльна оцінка безпосередніх та віддалених результатів лікування рецидивів варикозної хвороби вен нижніх кінцівок із трофічними виразками при використанні ендовенозних методик та класичної хірургії.

Матеріали та методи. У дослідження було включено 23 хворих із рецидивами варикозної хвороби вен нижніх кінцівок у стадії С6 після втручань 3 кросектомією, повторне хірургічне лікування яких проходило на базі відділення хірургії судин КЗ «Обласна клінічна лікарня ім. I.I. Мечнікова» (м. Дніпро), К3 «Міська лікарня №16» ДОР та МЦ «ЈМС». Загальна кількість чоловіків була 10 (43,5\%), жінок - 13 (56,5\%). Вік хворих коливався від 44 до 76 років (середній вік $56,5 \pm 7,9$ року). Середня часова різниця між первинною та коригуючою операцією склала $6,2+2,3$ року. Середній час рецидиву трофічних виразок склав $4,6 \pm 1,8$ року.

Пацієнтів було розділено на дві групи. В I групу було включено 12 пацієнтів, яким було проведено корекцію рецидиву шляхом повторної спроби кросектомії та хірургічного видалення вен шляхом стрипінгу та мініфлебектомії. У II групу ввійшли 11 пацієнтів, яким було проведено корекцію рецидиву шляхом комбінованих ендовенозних втручань 3 використанням радіочастотної абляції залишеної культі та невидаленої частини саженних стовбурів, склеротерапії зон неоваскуляризації та хірургічним видаленням варикозно-деформованих притоків. На момент початку обстеження групи хворих були співставними за основними критеріями.

Стандартне передопераційне обстеження включало збір анамнезу, фізикальне обстеження, фото фіксацію патологічних змін, оцінку тяжкості хронічного захворювання вен за шкалою VCSS (Venous Clinical Severity Score). Вираженість набряку фіксувалася шляхом вимірювання розміру окілу гомілки на рівні безпосередньо над медіальною кісточкою. Кожному хворому проводилося скринінгове ультразвукове дослідження (УЗД) в вертикальному і горизонтальному положенні. Виявляли кількість та параметри джерел рефлюксу у поверхневій венозній системі, шляхи його розповсюдження та точки, які заносилися до схеми венозної гемодинаміки. Наявність венозного рефлюксу крові фіксували за тривалості ретроградного кровотоку під термінальним клапаном тривалістю більше за 1 с, у діастолі після компресії литкових м'язів. Додатково в вертикальному положенні пацієнта вимірювали діаметр сафенофеморального з'єднання, довжину залишкової культі великої підшкірної вени.

Хірургічне втручання $з$ приводу рецидиву одномоментно проводилося тільки на одній кінцівці. Оцінювали наявність ускладнень під час операцій та у післяопераційному періоді, термін післяопераційного загоєння трофічних виразок, кількість рецидивів варикозної хвороби та виразок. Також проводили оцінку тяжкості хронічної венозної недостатності за шкалою VCSS (Venous Clinical Severity Score), Інтенсивність больового синдрому в першу післяопераційну добу вимірювали 3 використанням 10-бальної аналогової візуальної шкали. Задоволеність пацієнтів визначали шляхом анкетування у післяопераційому періоді.

Критеріями включення в дослідження були: клінічний рецидив венозних трофічних виразок після хірургічного лікування. Критеріями виключення 3 дослідження були: тромбоз глибоких вен на момент огляду або в анамнезі; порушення артеріального кровотоку зі зникненням пульсу більш ніж на одній 3 артерій ступні; рецидивуюча бешиха; малігнізовані виразки.

Усім хворим призначали стандартнее консервативне лікування, яке включало компресійну терапію (II клас компресії - гольфи UlcerKit), Детралекс 1000 мг на добу на весь період лікування, зміну пов'язок на післяопераційних ранах та виразках (за наявності), рекомендації щодо способу життя і режиму активності, в відповідності до чинних клінікопрактичних рекомендацій [10].

Ультразвукове скринінгове дослідження та інтраопераційний моніторинг проводився за допомогою сканерів General Electric Logiq Е з лінійним датчиком 5-7 МГц та General Electric Voluson $з$ лінійним датчиком 5-7 МГц.

Статистична обробка результатів проводилася 3 використанням пакетів программ MicrosoftExcel (Ліцензія: підписка Microsoft Office 365, ID 02984001-00000), StatPlus: mac (Analyst SoftInc., Stat Plus: тас. Версія 6, Ліцензія: №12083386). 
Визначалися середні величини [ $\mathrm{M} \pm \mathrm{m}]$, достовірність середніх величин за критерієм Стьюдента (t). Статистично достовірною вважалася різниця між показниками при $\mathrm{p}<0,05$.
Результати досліджень та їх обговорення. При проведенні передопераційного УЗ-обстеження були виявлені причини рецидиву у обох групах. Результати представлені у таблиці 1.

Таблиця 1

Причини рецидивів варикозної хвороби, виявлені на етапі передопераційного дослідження

\begin{tabular}{|l|c|c|}
\hline \multicolumn{1}{|c|}{ Причина рецидиву } & I група (n=12) & I група (n=11) \\
\hline $\begin{array}{l}\text { Рефлюкс по неспроможному інтактному стовбурі ма- } \\
\text { лої підшкірної вени }\end{array}$ & 2 & 4 \\
\hline $\begin{array}{l}\text { Рефлюкс по довгій (більше 1 см) культі сафени та по } \\
\text { передній додатковій сафенній вені }\end{array}$ & 3 & 2 \\
\hline $\begin{array}{l}\text { Рефлюкс по довгій (більше 1 см) культі сафени та } \\
\text { через зону неоваскуляризації на занадто довгому за- } \\
\text { лишеному неспроможному сафенному стовбурі }\end{array}$ & 4 & 1 \\
\hline Рефлюкс по передній арочній вені & & 2 \\
\hline Горизонтальний рефлюкс по перфорантних венах & 3 & 2 \\
\hline
\end{tabular}

Отримані дані використані для планування втручань.

Час повторного хірургічного втручання у I групі склав 2,1+-0,3 години, тоді як у II групі в середньому цей показник становив 1,2+-0,4 години.

При аналізі ускладнень: у I групі під час операцій виникло 2 епізоди (16,6\%) ушкодження культі сафени та зони неоваскуляризації в рубцевій муфті, внаслідок чого розвинулася кровотеча, яка була купована після підсилення хірургічної бригади. У ранньому післяопераційному періоді зафіксовано 1 $(8,3 \%)$ випадок формування значної гематоми у паховій зоні та 1 випадок післяопераційного тромбозу притоки на гомілці. Ускладнення у II групі -1 $(9,0 \%)$ випадок алергічної реакції на місцевий анестетик.

Через 2 місяці після проведення втручань венозні трофічні виразки загоїлися у 10 хворих $(83,3 \%)$ I групи та 11 хворих (100,0\%) II групи. Швидкість епітелізації виразок протягом всього періоду спостереження була співставною у обох групах і скла-

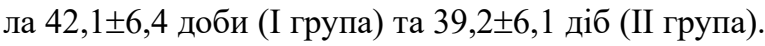
При цьому протягом першого місяця зменшення площі виразки, у відношенні ऑii у порівнянні зі станом перед операцією у хворих I групи у 2,3 $\pm 0,5$ ( $>>0,005)$, у хворих II групи у $2,1 \pm 0,4$ ( $>>0,005)$.

При цьому повторне відкриття виразки протягом дворічного періоду спостереження відбулося у 3 хворих (25,0\%) I групи. При УЗ-дослідженні у всіх них було виявлено значний горизонтальний рефлюкс по неспроможних перфорантних венах у підвиразковій ділянці. Рецидивів виразки у II групі не спостерігалося.

Середній показник інтенсивності післяопераційного больового синдрому у першу добу, виміряного за допомогою візуальної аналогової шкали, впродовж усього періоду спостереженя був дещо більшим у хворих I групи - 4,2+-1,2 проти 0,7+-0,2 у II групі. Це повною мірою визначило відсутність необхідності призначення знеболюю чих засобів після ендовенозних втручань.

Показник тяжкості хронічного захворювання вен, виміряний за шкалою VCSS, при незначному превалюванні у II групі $(7,4 \pm 4,0$ проти $7,3 \pm 3,2)$ перед початком дослідження, у післяопераційному періоді виявився меншим ніж у I групі на 37,3\% через 6 місяців. Результати представлені на рисунку 1 . 


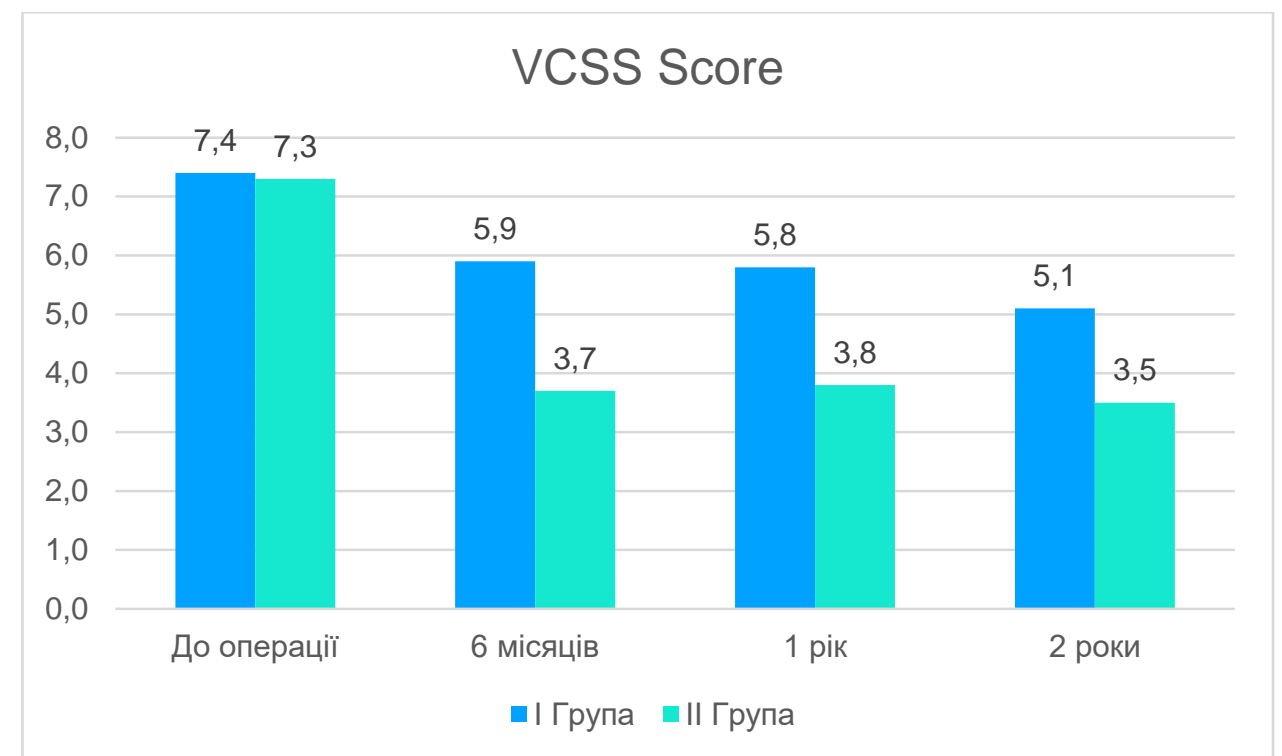

Рис. 1. Якість життя та важкість хронічної венозної недостатності - динаміка VCSS.

Кількість клінічних рецидивів без відкриття виразок протягом періоду спостереження виявлено у 4 хворих (33,3\%) І групи. Слід зазначити, що всі вони мали індекс маси тіла більше ніж 35. У II групі клінічний рецидив проявився у 1 хворого $(9 \%)$, натомість на УЗ-дослідженні протягом 2 років у II групі виявлено 2 (18,0\%) випадки анато-

мічного безсимптомного рецидиву внаслідок постабляційної реканалізації сафенного стовбура та вен підвиразкової ділянки, де проводилася склеротерапія. Дані представлені на рисунку 2. Цим хворим додатково призначені продовження використання компресійного трикотажу та планові етапні коригуючі втручання.

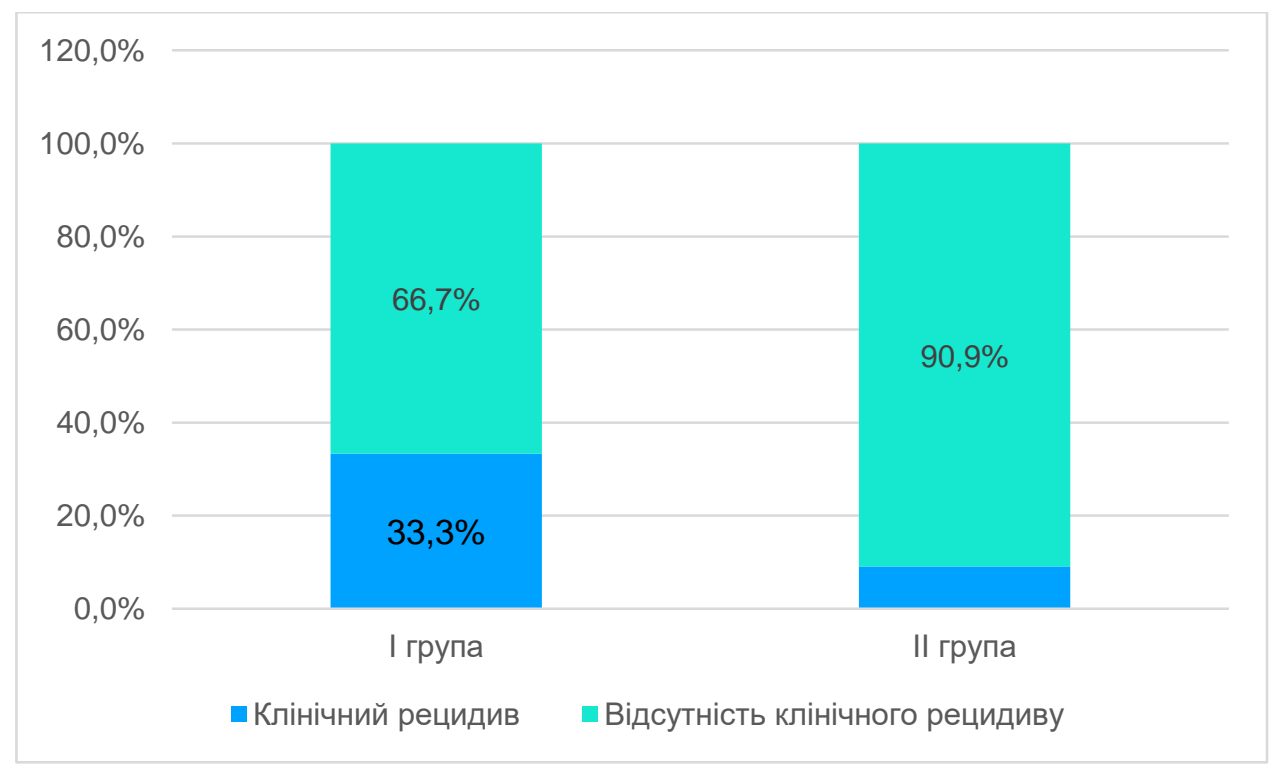

Рис. 2. Клінічні рецидиви після повторних втручань.

При опитуванні хворі II групи відзначали значно вищу задоволеність результатом лікування, аніж хворі I групи насамперед завдяки швидкій реабілітації та відновленню працездатності, що ймовірно $\epsilon$ наслідком малотравматичності втручань.

Висновки. Ретельне обстеження перед операцією, використання інтраопераційного УЗконтролю та моніторинг у післяопераційному періоді дозволяють зменшити кількість тактичних помилок у лікувальному процесі рецидивів варикозної хвороби.

Використання ендовенозних методів у лікуванні постхірургічних рецидивів варикозної хвороби вен нижніх кінцівок дозволяє досягти співставної ефективності результатів лікування та меншої кількості ускладнень.

Ініормація про конфлікт інтересів. Автор не має конфліктів інтересів пов’заних з цим рукописом. 
Інформація про фінансування. Автор не отримував ніяких винагород ні в якій формі від фірмвиробників лікарських препаратів, медичного обладнання та матеріалів, у тому числі конкурентів, здатних вплинути на результати роботи.

\section{Особистий внесок автора:}

Соколов О.В. - огляд літератури, дизайн дослідження, відбір пацієнтів, статистична обробка, написання статті, редагування та вичитка статті

\section{Список використаної літератури}

1. Herman J, Musil D, Tichy M, Bachleda P. Recurrent varicose veins: causes and neovascularisation. A 17-year experience. IntAngiol. 2015 Feb;34(1):53-9.

2. O’Donnell TF, Balk EM, Dermody M, Tangney E, Iafrati MD. Recurrence of varicose veins after endovenous ablation of the great saphenous vein in randomized trials. J VascSurgVenousLymphatDisord. Elsevier; 2016 Jan 1;4(1):97-105.

3. Recurrent Varices after Surgery (REVAS), a Consensus Document:. SAGE PublicationsSage UK: London, England; 2016 Aug 27.

4. Rasmussen L, Lawaetz M, Serup J, Bjoern L, Vennits B, Blemings A, et al. Randomized clinical trial comparing endovenous laser ablation, radiofrequency ablation, foam sclerotherapy, and surgical stripping for great saphenous varicose veins with 3-year follow-up. J VascSurg Venous LymphatDisord. Elsevier; 2013 Oct $1 ; 1(4): 349-56$.

5. Gloviczki P. et al. (ed.). Handbook of Venous and Lymphatic Disorders: Guidelines of the American Venous Forum. - CRC Press, 2017.

6. Winokur RS, Khilnani NM, Min RJ. Recurrence patterns after endovenous laser treatment of saphenous vein reflux:. Phlebology. SAGE PublicationsSage UK: London, England; 2015 Jul 16;31(7):496-500.

7. Nelzen O. Great uncertainty regarding treatment of varicose vein recurrence. Phlebologie. 2018 Jan $5 ; 43(01): 13-8$.

8. Meneses L, Fava M, Diaz P, Andía M, Tejos C, Irarrazabal P, et al. Embolization of Incompetent Pelvic Veins for the Treatment of Recurrent Varicose Veins in Lower Limbs and Pelvic Congestion Syndrome. CardiovascInterventRadiol. Springer-Verlag; 2012 May 1;36(1):128-32.

9. Jacob P. Recurrent Varicose Veins. Chronic Venous Disorders of the Lower Limbs. Springer, New Delhi; 2015: 95-103.

10. Usenko E. Khronicheskiezabolevaniyavennizhnikhkonechnostey i taza: diagnostika, lechenie, laboratornyykontrol', profilaktikaoslozhneniy / E. Usenko, P. Nikul'nikov, L. Chernukha [et al.] // Klinicheskie i prakticheskierekomendatsii. Kyiv, 2014. 120 s. Russian.

Стаття надійшла до редакції: 17.02 .2020 р. 